\title{
Correction: Molecular phylogeny of Salmo of the western Balkans, based upon multiple nuclear loci
}

\author{
Gašper Pustovrh", Aleš Snoj and Simona Sušnik Bajec
}

\section{Correction}

After publication of this work [1], we noted that the same mistake occurs in Table one, Figure one, Figure two, Figure four and on page 6 (Result section). In these places of the article, we wrote that the two brown trout samples of the Mediterranean (ME) lineage came from Sardinia, which is not the case. These two samples of the ME lineage were taken from the small river Caranca, a tributary of the Tet River in France and this lineage carried a single mtDNA haplotype MEcs3. Samples were provided by Patrick Berrebi.

Received: 19 March 2014 Accepted: 19 March 2014

Published: 23 April 2014

\section{Reference}

1. Pustovrh G, et al: Molecular phylogeny of Salmo of the western Balkans, based upon multiple nuclear loci. Genet Sel Evol 2014, 46:7.

Submit your next manuscript to BioMed Central and take full advantage of:

- Convenient online submission

- Thorough peer review

- No space constraints or color figure charges

- Immediate publication on acceptance

- Inclusion in PubMed, CAS, Scopus and Google Scholar

- Research which is freely available for redistribution 